\title{
The Extent of Voluntary Disclosure Before and After IFRS Convergence in Indonesia
}

\section{A. Totok Budisantoso ${ }^{1}$ and Maria Eliza Suryanto ${ }^{2}$}

\author{
${ }^{1}$ Atma Jaya Yogyakarta University, Indonesia, e-mail: totok bs@yahoo.com \\ ${ }^{2}$ Atma Jaya Yogyakarta University, Indonesia
}

\begin{abstract}
This research aims to prove empirical result whether there is a significant increase on the extent of voluntary disclosure after the IFRS convergence in Indonesia. Utilizing the manufacturing companies listed in Indonesian Stock Exchange (IDX) as the samples, this research selects two years before the IFRS convergence and two years after the IFRS convergence in Indonesia. Voluntary disclosure index is used to develop the score of the voluntary disclosure for each company. The index of voluntary disclosure was taken from Botosan (1997) and Meek (1995). The results show that there is a significant increase in the extent of voluntary disclosure after the IFRS convergence in Indonesia. This finding implies that companies may be motivated to provide more voluntary disclosures with the objective of finding the necessary funds on better terms and carrying out effectively their expansion plan. It provides signals of lower earnings management and would subsequently reduce information uncertainty and satisfy investors' information needs.

Keywords: International Financial Reporting Standard (IFRS) Convergence, Voluntary Disclosure
\end{abstract}

\section{Introduction}

Investors, as one of the company's sources of fund, reserve the right to get all information related to the condition of the company especially the company's financial condition. The obtained information can be the consideration for them whether to invest their money, to continue investing on the company, or to pull back their money from the company. Thus, a media of information is needed in helping the investors to get useful information about the company's financial condition. That information media is the financial report. There are many things which are disclosed by the company in the financial report. SFAC no.8 stated that the general objective of financial reporting is to provide financial information about the reporting entity that is useful to existing and potential investors, lenders, and other creditors in making decisions about providing resources to the entity. Those decisions involve buying, selling, or holding equity and debt instruments and providing or settling loans and other forms of credit. Moreover, firms that disclose more accounting information would tend to be positively greeted by the stock market as they would be perceived as good and honest companies (Apostolou and Nanopulous, 2009, Goncharovet et al., 2006).

The thing that makes it different from one to another financial report is the standard of the accounting standard which is applied in the country where the company stands. There are two big international accounting standards which are applied in almost all over the world, they are US GAAP and IFRS. USGAAP and IFRS have some differences, and one of the differences is that the US GAAP is an accounting standard with Rule-Based principle while IFRS is Principle-Based principle. The rulebased principle itself is a principle which involves high levels of standardization, while principlebased involves flexibility in financial reporting and judgment.

There are two ways to adopt IFRS into national accounting standard. The first one is by adopting all the regulations inside IFRS into national accounting standard, which is usually called by full adoption. The second one is by adopting only some parts inside IFRS to be translated into national accounting with some adjustment, which is usually called by convergence process.

The transition of accounting standard from US GAAP to IFRS reference is caused by of the fact that Indonesia is one of the G-20 members. All the G-20 members had made an agreement and one of the agreements is synchronizing or harmonizing the accounting standard in each member country with 
the international accounting standard which can be accepted in all over the world. That accounting standard is the IFRS based accounting standard.

Ikatan Akuntan Indonesia (IAI, 2012) stated that the purpose of the IFRS convergence into PSAK is to minimize the difference between the financial report based on SAK and IFRS. The benefit of this convergence is helping the users to understand the financial report, the financial report is appropriate with the financial accounting standard, which is internationally applicable, and making the financial report forming more efficient, increasing the investment flow by transparency enhancement, and decreasing the cost of capital.

The history of the Indonesian accounting standard transition began from the adoption of the US GAAP which had been translated into the "old" PSAK. It had been used from 1974 until 1999. In 1999, IAI decided to make changes on that standard which was matched to the market condition in Indonesia at that time. In 2008, the IFRS standard was announced in Indonesia. Moreover, Indonesia is one of the G-20 members and should apply the accounting standard with IFRS standard. It has been announced in the agreement of G-20 Summit. Why they told all the members to use the same accounting standard, it is because with the same accounting standard each of the country can trade easier. Moreover, the same accounting standard applied by the members of G-20 will help the investors to compare the financial statements in Indonesian companies and other countries' companies. So, to fulfill the commitment of G-20 Indonesia had made changes in the accounting standard by converging the accounting standard in IFRS into PSAK gradually from 2009, while the first introduction of the IFRS concept in Indonesia had already declared in 2008 and it has been fully adopted since 2012 .

The transition from U.S. GAAP into IFRS gave some changes on the characteristic of the accounting standard itself. The U.S. GAAP is rule-based while IFRS is principle based. Rule based involves high level of standardization while IFRS which is principle based only regulate the primary things on the standard while the procedure and policy depend on the user (Indrawati, 2014).

The implementation of IFRS in Indonesia is expected to give different impact on the extent of voluntary disclosure, especially it is expected to increase the extent of voluntary disclosure. This study uses voluntary disclosure checklist with certain weighting score for each item disclosed. The total mean of the score obtained by the company will be used to determine whether there is an increase in the voluntary disclosure's extent after the IFRS convergence. As the sample, this study uses the manufacturing companies listed in Indonesian Stock Exchange with two periods which are two years before IFRS convergence (2010-2011) and two years after the adoption (2012-2013).

The research problem can be formulated as follows: Does the extent of the voluntary disclosure increase significantly after IFRS adoption for the manufacturing companies listed in Indonesia Stock Exchange (IDX)?

The objective of this research is to obtain empirical evidence that there is an increase on the score of the voluntary disclosure after IFRS convergence into Indonesian GAAP (PSAK) in the manufacturing companies listed in Indonesian Stock Exchange.

Theoretical Background and Hypothesis Development. The agency relationship arises when both principal (investors or owner) and agent (managers) have a contract which is binding to each other. Commonly, agent and principal have their own interest. The principal wants the agent to work hard or give some effort to provide what the principal wants. On the other side, the nature of the agent's effort is too complex for the principal to observe it directly (Scott, 2015). So, the principal probably doesn't exactly know whether the agent is already providing them enough and honest information or not. This is caused by information asymmetry, since the agent has more information related to the company than the principal. The information asymmetry itself can give impact to the investors' decision making, so it is hoped that the company will give or disclose more information to the principal.

Disclosure can be interpreted as information which are not posted in the financial report itself, or the disclosed of something like management discussion and analysis, footnotes, and supplementary 
report (Hendriksen and Breda, 1992). The purpose of disclosure in the financial statements by Chariri and Ghozali (2007: 382) are:

1. Providing useful information to investors, creditors and other users in making rational decisions.

2. Providing information to help investors, creditors and other users assess the amount, recognition of net cash receipts.

3. Providing information about the economic resources of a company.

4. Providing information about business results (financial performance) of a company for 1 period.

5. Providing information which are useful for managers and directors in the interests of the owner.

6. Comparing each company and each year to the others, which aims to provide information on incoming and outgoing cash inflows in the future.

7. Assisting investors in determining return and investment.

There are 2 kinds of disclosure seen from the obligation to share the information, they are mandatory disclosure and voluntary disclosure. Mandatory disclosure is disclosure which is minimum required by law. Voluntary disclosure is disclosure held by the company outside what is required by law and it could be informative or sensitive information relating to the economic environment, corporate governance, management judgment, etc.

In voluntary disclosure the company is free to disclose any kind of information related to the financial condition, outside what is required by the regulation. Managers may provide voluntary accounting disclosures in order to illustrate and communicate in further detail their financial policies, their decisions and actions and other explanatory information. The disclosure of voluntary information would seek to reduce uncertain information asymmetry and skepticism, and would tend to reinforce investor's confidence on the company's management (Dye, 1998).Lower uncertainty would reduce the need for monitoring management actions and would consequently lead to lower debt contracting costs and higher firm value (Gietzmann and Trombetta, 2003). Companies may choose to provide voluntary disclosures in order to limit investors' potential adverse perceptions and create expectations about the companies' prospects (Barth et al., 2008).

Figure 1. IFRS convergence

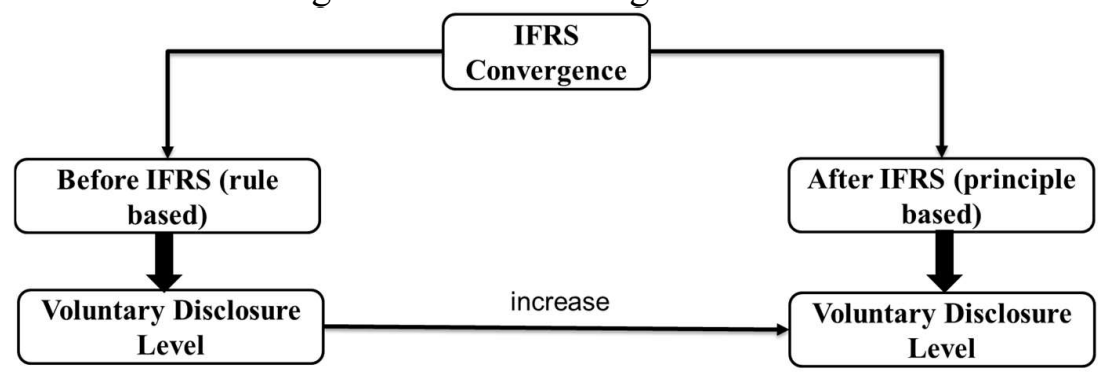

There was a transition in Indonesian Accounting Standard from U.S. GAAP into IFRS. It happened because Indonesia is one of G-20 members where it is a must for the members to provide financial report with IFRS to make it more comparable not only in local area but also in the broader or international area. U.S. GAAP based and IFRS based accounting standard is different. The character of Us. GAAP is rule-based which means it involves high level of standardization or contains of specific rules (Iatridis and Alexakis, 2012). On the contrary, the character of IFRS is principle-based. Principle-based doesn't have bright-line or specific rules. The principle-based characteristic also makes the absence of highly prescriptive financial reporting guidance, so the decision making should emphasize on professional judgment. Professional judgment can be made correctly if the information disclosed by the company were provided and can be accessed easily. It means that when the company discloses information, better professional judgment can be made.

IFRS standards are commonly deemed to be more principle based than local GAAP in many adopting countries (Ball, 2006). Disclosure increases transparency while market transparency is observed as a 
fundamental mechanism in order to decrease the information asymmetry among the market's participants (Bleck et al., 2007).Companies might be motivated to provide voluntary disclosures, in order to obtain easier access to domestic and international capital markets or to facilitate their growth process(Iatridis and Alexakis, 2012).

The change in Indonesian PSAK from the US GAAP reference to the IFRS reference will give some changes to the financial and non-financial information disclosed, especially to the positive changes. One of the examples which shows the difference between PSAK before and after IFRS convergence, which gives impact to the increase of voluntary disclosure, is PSAK 22 about business combination. PSAK 22 revision 2009 stated about all the regulations on what should be disclosed while PSAK 22 revision 2012 stated about the possibility of the company to disclose more information. It is proved by a paragraph that can be found in PSAK 22 revision 2012, especially paragraph 63 on disclosure part. It is stated that if the specific disclosure which is required by this statement and other SAK doesn't achieve the specified goal in paragraph 59 and 61, the acquisition party discloses all additional information needed to achieve that. Paragraph 59 itself stated about the disclosure of information which makes the user of financial report can evaluate the characteristics and financial impact on that business combination, while paragraph 61 stated about the disclosure of information that makes the user of financial report can evaluate the financial impact. The evaluation is from the adjustment which is admitted on the reporting period related with business combination. This might be implied that the "new" PSAK 22 allows company to voluntarily disclose information related to business combination on their reporting to fulfill the specific goal in paragraph 59 and 61.

Research about whether there is an increase in the extent of voluntary disclosure after IFRS was adopted or converted into the local accounting standard has been conducted by some researchers. One of the prior researches was done by Silvia Consoni and Romualdo Douglas Colauto (2016), by using 66 Brazilians companies which are listed as active companies in BM\&Fbovespa during 2005 until 2012 as the sample. From this research, they found that the convergence process to IFRS was presented as an exogenous factor that affected positively and significantly voluntary disclosure in the analyzed period. It led to the complementary rationale between mandatory disclosure and the voluntary disclosure.

George Emmanuel Iatridis (2012) had already conducted a research about voluntary IFRS disclosure with the evidence from the transition from UK GAAP to IFRSs. Using Gray's (1980) comparability index, the study found that voluntary IFRS disclosures generally experienced a positive change while moving to IFRSs. Firms that disclosed IFRS-related information in the pre-official IFRS adoption period tend to exhibit stronger financing needs. The study also showed that voluntary IFRS disclosures were larger and visible in the market and displayed a significant growth potential.

The study explained managerial behavior with respect to the managerial choice to disclose voluntary accounting information. It implied that firms would tend to provide voluntary (IFRS) disclosures when it was managerially beneficial. The need to obtain financing on better terms would motivate managers to provide voluntary (IFRS) disclosures to show that they were familiar with the upcoming regulatory change and ready to implement it when it became effective. This would imply that voluntarily providing unfavorable and financially adverse disclosures would improve the firms' financial credibility. Voluntary disclosures would also motivate managers to focus on problematic areas and improve their financial position. This would tend to be more intensive in countries with strong investor protection mechanisms where the demand for public disclosure was stronger.

Another study about the IFRS adoption and voluntary disclosure was done by Jose Elias Feres de Almeida and Herbert Simoes Rodrigues (2015). Their research used the Brazilian Public Companies which were listed on the Sao Paulo Stock Exchange (Bovespa) as the sample with totaling 674 observations between 2006 and 2013. The result showed that all disclosure indexes increased during the IFRS adoption periods. One of the evidences of the research was there was positive association

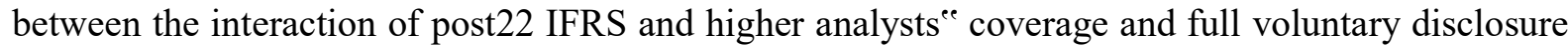
index and disclosure of social and environmental information. The conclusion of this research was 
that post-IFRS period affected voluntary disclosure negatively, however post-IFRS affected voluntary disclosure positively in the firms with higher covered by analysts and American Depositary Receipts listing.

The previous study in Brazil, conducted by Consoni \& Colauto (2016) also claimed that the IFRS convergence process was presented as an exogenous factor that affected positively and significantly voluntary disclosure in the analyzed period.

Thus, from the explanation above the formulation of the hypothesis is:

Ha: There is a significant increase on the extent of voluntary disclosure after IFRS convergence in Indonesia

\section{Research Methodology}

The population used in this research was the manufacturing companies listed in IDX on the period of 2010-2013 using purposive sampling with some criteria as follows:

Table 1. Research Sample

\begin{tabular}{|l|l|l|}
\hline No. & \multicolumn{1}{|c|}{ Criteria } & \multicolumn{1}{|c|}{ Total } \\
\hline 1. & $\begin{array}{l}\text { Manufacture companies listed in Indonesian Stock Exchange in a period between } \\
2010-2013\end{array}$ & 127 \\
\hline 2. & $\begin{array}{l}\text { Manufacture companies which are delisted from Indonesian Stock Exchange } \\
\text { between 2010-2013 }\end{array}$ & $(3)$ \\
\hline 3. & Unavailable data in the Indonesian Stock Exchange website & $(37)$ \\
\hline 4. & $\begin{array}{l}\text { Unavailable anymore in Indonesian Stock Exchange because the companies were } \\
\text { delisted in a period between 2014 - now }\end{array}$ & $(4)$ \\
\hline & Total Sample & 83 \\
\hline & Observation & 4 years \\
\hline & Total Sample Observation & 332 \\
\hline
\end{tabular}

This research used secondary data which were the annual reports of the manufacturing companies from 2010-2013 accessed from Indonesian Stock Exchange (idx.co.id). The variable of this research was the total score of voluntary disclosure. The media implemented to know the total score of voluntary disclosure was the voluntary disclosure index by Botosan (1997) and Meek (1988) which were adjusted with the local regulation, so the items which were becoming mandatory in the local regulation would be excluded in the index. Each item disclosed had the weighting value from 0 until 3 depended on each category. The voluntary disclosure items and the consideration of the weighting score for each item were displayed on the appendix.

The total score of voluntary disclosure would be calculated into Voluntary Disclosure Ratio which could be calculated as follows (Hossain et al., 2009):

$$
V D R=\sum_{i=1}^{m} d_{i} / m
$$

Where :

$V D=$ Voluntary Disclosure Ratio

$d i=$ Total items disclosed

$\mathrm{m}=$ Total item which included in the voluntary disclosure checklist or the maximum score 
To compare the result of the Voluntary Disclosure Ratio between before and after IFRS convergence was by calculating its mean from 2 years before (2010-2011) and 2 years after (2012-2013) the IFRS Convergence as follows:

1. $V D R$ meanbefore $=\frac{V D R(t-2)+V D R(t-1)}{2}$

Where:

$\mathrm{t}-1=$ Voluntary Disclosure Ratio in 2011

$\mathrm{t}-2=$ Voluntary Disclosure Ratio in 2010

2. $V D R m e a n a f t e r=\frac{V D R(t+1)+V D(t+2)}{2}$

Where:

$\mathrm{t}+1=$ Voluntary Disclosure Ratio in 2012

$\mathrm{t}+2=$ Voluntary Disclosure Ratio in 2013

\section{Result and Discussion}

Table 2. Descriptive Statistics

\begin{tabular}{|l|r|r|r|r|r|}
\hline & $\mathrm{N}$ & Minimum & Maximum & \multicolumn{1}{c|}{ Mean } & $\begin{array}{c}\text { Std. } \\
\text { Deviation }\end{array}$ \\
\hline beforeIFRS & 83 & .00000 & .36364 & .1190215 & .06907449 \\
afterIFRS & 83 & .01515 & .37879 & .1431179 & .07916410 \\
Valid N & 83 & & & & \\
(listwise) & & & & & \\
\hline
\end{tabular}

From the data description table 2, it could be known that from the variable of before IFRS Convergence the mean was 0,119 , with the standard deviation of 0,069 , while the minimum point was 0,00 , and the maximum point was 0,3636 . From the other variables, which were variable after IFRS Convergence, it could be known that the mean was 0,143 , with the standard deviation of 0,079 , while the minimum point was 0,015 , and the maximum point was 0,3787 .

Hypothesis Testing. The Wilcoxon Sign Rank Test is a non-parametric test which is used to proceed two related data on this research. Wilcoxon Sign Rank Test doesn't need the data to be normally distributed. The result of this Wilcoxon Sign Rank Test will be used to make an analysis whether there is an increase on the extent of voluntary disclosure after the IFRS Convergence in Indonesia or not. The criteria to test whether Ha is accepted is sig. $<0,05$ and the Voluntary Disclosure Ratio's mean before IFRS Convergence $<$ The Voluntary Disclosure Ratio's mean after IFRS Convergence. The result of the Wilcoxon Sign Rank test proceeds by using SPSS 17.0 is presented below:

Table 3. Wilcoxon Sign Rank Test Result. Test Statistics ${ }^{b}$

\begin{tabular}{|l|l|}
\hline & afterIFRS - beforeIFRS \\
\hline Z & $-4.667^{\mathrm{a}}$ \\
Asymp. Sig. (2-tailed) & .000 \\
\hline
\end{tabular}

a. Based on negative ranks.

b. Wilcoxon Signed Ranks Test

The result that could be obtained from table 3 was that the sig. (2-tailed) was 0,000. Because this research wants to uncover whether there was an increase number on voluntary disclosure ratio, the significant number which was used to know the result was by looking at the sig. (1-tailed) result. 
From the result's table, it was known that sig. (2-tailed) was 0,000 while the sig. (1-tailed) was the result of sig. (2-tailed) divided by 2 which the result was the same 0,00 . It could be concluded that there was an increase on the extent of voluntary disclosure after IFRS convergence in Indonesia.

Discussion. Based on the result from hypothesis testing using Wilcoxon Signed Rank test to test the two related samples, Ha is accepted. If Ha is accepted, it means that there is an increase on the extent of voluntary disclosure after IFRS convergence in Indonesia. This result shows that since the IFRS has already been fully implemented in Indonesia, which started on January 1, 2012, the convergence gives significant impact on the extent of voluntary disclosure among manufacturing companies listed in Indonesia Stock Exchange (IDX).

This happens because Indonesian economic regulation has done the convergence from referred to U.S. GAAP which is rule-based into IFRS which is principle-based. The rule-based itself has rigid regulation while principle-based is not so rigid in containing the regulation. The standard with principle-based doesn't have bright lines or specific rules and when the principle-based characteristic also makes the absence of highly prescriptive financial reporting guidance, making the decision should emphasize on professional judgment.

Because it is not so rigid in containing the regulation, investors and analysts need more detailed information to make professional judgment or decision. To make a professional judgment, investors need more information from the company. If the company provides more information to the investors, it can also reduce the information asymmetry which means reducing uncertainty and giving assurance to domestic and foreign investors about the quality of their financial reporting. When information asymmetry can be reduced, it means that the company can also reduce the agency cost which arises between the agent and the principal since they have their own interest. Therefore, that situation pushes up the extent of the voluntary disclosure.

This result is consistent with the result from the research conducted by Silvia Consoni and Romualdo Douglas Colauto (2016) in which there was an increase of voluntary disclosure after the IFRS convergence in Brazil. They stated that the changes in accounting regulation in Brazil may have led companies to take greater commitment to voluntary disclosure in terms of content and extent. Moreover, cited from Leuz\&Verrecchia (2000) the provision of information to the market reduces the information asymmetry and consequently leads to significant and positive relationship between liquidity and voluntary disclosure.

The increasing extent of the voluntary disclosure also might be correlated with the agency theory. Companies may be motivated to provide more voluntary disclosures with the aim to be able to attract the necessary funds on better terms and effectively carry out their expansion plan in the effort to stabilize and secure their growth process (Iatridis\&Alexakis, 2012). Furthermore, the more voluntary disclosure disclosed to the public, the more uncertainty and skepticism reduced. It is because the voluntary accounting disclosures would give a positive signal to investors about the intention of the company to diligently inform users of accounting information and to provide them with explanatory notes and informative reports (Iatridis\&Alexakis, 2012).

Firms that disclose more accounting information would tend to be positively greeted by the stock market as they would be perceived as good and honest companies (Apostolou and Nanopoulos, 2009; Goncharov et al., 2006). Firmsthat voluntarily disclose information would provide signals of lower earnings management and would subsequently reduce information uncertainty and satisfy investors' information needs (Anctil et al., 2004).

\section{Conclusion}

The result of the test shows that Ha is accepted. It means that there is an increase on the extent of voluntary disclosure on Indonesian manufacturing companies between before and after IFRS convergence in Indonesia. The increase of the extent of voluntary disclosure after the IFRS convergence is caused by the characteristic of the IFRS itself which is principle-based. Principlebased means that IFRS is emphasizing more on interpretation and application of standard, moreover 
it requires an assessment of the substance of transaction and evaluation whether the accounting presentation reflects the economic reality. So that, it requires more professional judgment on the application of accounting standard.

Because it needs more professional judgment, of course the investors or the outside users of financial reporting need more information related to the condition of the company itself. Disclosing more information related to the company's condition also can reduce the information asymmetry, where it also gives good impacts to the company itself.

The limitations of this research are: the sample used in this research are only the manufacture companies because most of the items on the disclosure checklist are only suitable for manufacture companies, the period of this research is only 2 years before and 2 years after the IFRS adoption in Indonesia. The suggestions for the next research are that the next research can do the research by using the sample outside the manufacture companies, so that the research can give information whether the IFRS convergence also can give impact on the extent of voluntary disclosure on the companies outside manufacture companies and the period of the research can be taken for a longer time to get a more significant result.

\section{References}

Almeida, J. E. F., and Rodrigues, H. S. (2015). Effects of IFRS, Analysts and ADR on Voluntary Disclosure of Brazilian Public Companies. Forum de Pesquisa do PPGCC - FEA - USP, Sao Paulo, SP, Brasil.

Anctil, R., Dickhaut, J., Kanodia, C. and Saphiro, B. (2004). Information transparency and coordination failure: theory and experiment. Journal of Accounting Research, Vol. 42 No. 2, pp. 159-195.

Apostolou, A. and Nanopoulos, K. (2009). Voluntary accounting disclosure and corporate governance: evidence from Greek listed firms. International Journal of Accounting and Finance, Vol. 1 No.. 4, pp. 395-414.

Ball, R. (2006). International financial reporting standards (IFRS): Pros and cons for investors. Accounting and Business Research, 36(Suppl.), 5-27.

Barth, M., Landsman, W. and Lang, M. (2008). "International accounting standards and accounting quality". Journal of Accounting Research. Vol. 46 No. 3, pp. 467-98.

Bleck, A., and Liu, X. (2007). Market Transparency and the Accounting Regime. Journal of Accounting Research 45(2), 229-256.

Botosan, Christine A. (1997). Disclosure Level and the Cost of Equity Capital. The Accounting Review Vol. 72, No. 3, July 1997, pp. 323-349.

Chariri, Anis dan Gozali, Imam. 2007. Teori Akuntansi. Badan Penerbit Universitas Diponegoro, Semarang.

Choi, F.D.S and Meek, G. K. (2005). International Accounting. Upper Saddle River/New Jersey: Pearson Prentice Hall.

Consoni, Silvia \& Romualdo Douglas Colauto. (2016). Voluntary Disclosure in the Context of Convergence with International Accounting Standards in Brazil. Review of Business Management, Sao Paulo, Vol. 18, No. 62, p. 658-677, Oct./Dec. 2016.

Doupnik, Timothy \& Perera, Hector. (2007). International Accounting. Singapore: McGraw-Hill Companies, Inc.

Dye, R. A. (1998). Investor sophistication and voluntary disclosure. Review of Accounting Studies, 3(3), 261-287.

Gietzmann, M. And Trombeetta, M. (2003). Disclosure interactions: accounting policy choice and voluntary disclossure effects on the cost of raising outside capital. Accounting \&Business Research. Vol. 33 No. 3, pp. 187-205.

Gigler, F. And Hemmer, T. (2001). Conservatism, Optimal Disclosure Policy, and the Timeliness of Financial Reports. The Accounting Review, 76: 471-93. 
Godfrey, Jayne, et al. (2010). Accounting Theory, 7th edition. Singapore: John Wiley \& Sons Australia, Ltd.

Goncharov and Zimmerman. (2006). Do Accounting Standard Influence the Level of Earnings Management? Evidence from Germany.

Hendriksen, Eldon S. And Breda, M. (1992). Accounting Theory : Fifth Edition. American Institute of Certified Public Accountants, Inc.

Huse, Morten. (2007). Boards, Governance and Value Creation. Cambridge.

Iatridis, George \& Panayotis Alexakis. (2012). Evidence of Voluntary Accounting Disclosures in the Athens Stock Market. Review of Accounting and Finance, Vol. 11 Iss 1 pp. $73-92$

Iatridis, George Emmanuel. (2012). Voluntary IFRS disclosures: evidence from the transition from UK GAAP to IFRSs. Managerial Auditing Journal, Vol. 27 No. 6, 2012 pp. 573-597

Ikatan Akuntan Indonesia. (2008). Sejarah SAK. Accessed from : http://www.iaiglobal.or.id/v02/prinsip_akuntansi/standar.php?cat=SAK\%20Umum

Ikatan Akuntan Indonesia. (2012). Standar Akuntansi Keuangan; Per 1 Juni 2012. Jakarta: Ikatan Akuntan Indonesia.

Indrawati, Novita. (2014). Pengaruh Karakteristik Perusahaan Terhadap Adopsi Sukarela International Reporting Standards di Indonesia. Jurnal Akuntansi, Vol. 2, No. 2, April 2014 : 114-126.

Kurniawan, Yulius Adi. (2013). Faktor-Faktor yang Memengaruhi Luas Pengungkapan Sukarela pada Laporan Tahunan Perusahaan di Bursa Efek Indonesia. S1 thesis, UAJY.

Lang, M. H., \& Lundholm, R. (2000). Voluntary Disclosure and Equity Offerings Reducing Information Asymmetry or Hyping the Stock?". Contemporary Accounting Research, 17(4), pp. 623-662.

Leuz, C., \& Verrecchia, R. E. (2000). The economic consequences of increased disclosure. Journal of Accounting Research, 38(Suppl.), 91-124.

Meek, G. K., Roberts, C. B., \& Gray, S. J. (1995). Factors influencing voluntary annual report disclosures by U.S., U.K. and continental European multinational corporations. Journal of International Business Studies, 26(3), 5-572.

Miihkinen, Antti. (2008). Efficiency of Authoritative Disclosure Recommendations : Evidence from IFRS transition disclosure in Finland. Journal of Financial Regulation and Compliance. Vol. 16 No. 4, 2008 pp. 384-413. Emerald Group Publishing Limited 1358-1988.

Ranette, Dine. (2014). Faktor-Faktor yang Mempengaruhi pengungkapan Sukarela pada Perusahaan Manufaktur di Bursa Efek Indonesia. Jurnal Bisnis dan Akuntansi Vol. 16, No. 1a, Is. 4, November 2014, Hlm. 97-110.

Riahi, A., \& Belkaoui. (2004). Accounting Theory, 5th edition. Singapore: Thomson Learning.

Santoso, Singgih. (2010). Statistik Nonparametrik: Konsep dan Aplikasi dengan SPSS. Jakarta: PT. Elex Media Komputindo.

Scott, William R,. (2015). Financial Accounting Theory: 7th edition. Pearson Canada Inc.

Sekaran, Uma \& Roger Bougie. (2010). Research Methods for Business. Wiley.

Silviana, Yohana Heru Krisna. (2014). Perbedaan Tingkat Pengungkapan Antara Perusahaan Asing dan Domestik dengan Adanya Konvergensi IFRS. S1 thesis, UAJY. 